\title{
Implementation of EM Algorithm in Opinion Mining Movies Review Case Studies
}

\author{
${ }^{(1)}$ Muhammad Danial Romadloni, ${ }^{(2)}$ Indra Gita Anugrah \\ Universitas Muhammadiyah Gresik, Indonesia \\ E-mail: ${ }^{(1)}$ danial_170602@umg.ac.id, ${ }^{(2)}$ indragitaanugrah@umg.ac.id
}

Received: 14 May 2021; Revised: 17 October 2021; Accepted: 15 November 2021

\begin{abstract}
One of the websites that often used to review movies we had watched is IMDb. That data review can be used for opinion mining, whether the movie being reviewed was good or not. One of the algorithms that are often used for opinion mining is Naïve Bayes, apart from being easy to implement and used, Naïve Bayes is also known to be very fast to predict classes on a test dataset. The purpose of this study is to see how much influence the Expectation-Maximization to increase accuracy on opinion mining movies review case studies. From the results of this study uses 878 training datasets that consist of the half with the positive label and another half with the negative label from IMDb's movie reviews and 577 as testing datasets. Accuracy that Naïve Bayes got is $67 \%$ but after the uses of EM as the alternative algorithm of Naïve Bayes, the accuracy that EM got is $71 \%$. Using the EM method, it was found that the accuracy increased by $4 \%$ compared to using Naïve Bayes.
\end{abstract}

Keywords: Opinion mining; Sentiment analysis; Expectation-Maximization; Naïve Bayes;

\section{Introduction}

Opinion mining becomes one of the most widely adopted topics by researchers. This is mainly supported by the easier it is to get datasets from the internet and if we talk about the internet, we could imagine how big the data is. Especially the data reviews for movie domain which one of the common websites that holds this kind of datasets is IMDb. In IMDb, one could see that all the reviews written by the users, not only movie title that released recently but also from years ago. Thus, confirms that how easy it is to get the datasets for this particular domain which is movie domain for opinion mining. The general algorithm that used for opinion mining and sentiment analysis is Naïve Bayes. There are three main components of opinion mining and analysis methods such as pre-processing, feature extraction and classification (Kulkarni \& Rodd, 2018. Many research that uses Naïve Bayes as classifier algorithm for instances (Vijay et al., 2020 for product review data from amazon, (Harahap et al., 2019 for predicting purchase, (Ilham Esa Tiffani, 2020 for hotel review, (Pugsee \& Chatchaithanawat, 2020 for laptop reviews and (Pugsee et al., 2019 skin care products on twitter, also (Poovaraghan et al., 2019 and (Granik \& Mesyura, 2017 for fake news detection applications. Another research that similar (with this study in movie domain) although not identical (Novendri et al., 2020 uses data from YouTube comments also using Naive Bayes for the classification. All the previous studies that the author mentions share the same though that Naïve bayes do the job well. Unfortunately, most of the data from the internet are unstructured. In (Kulkarni \& Rodd, 2018 the author states that the accurate identification of content features gathered from the unstructured textual data is major research challenge. Therefore, it is a must to design an efficient technique which will be able to identify such features from 
the unstructured datasets (Kulkarni \& Rodd, 2018. Therefore, an alternative or at least an optimization of the current algorithm is needed in some applications. As addition, in (Zhou et al., 2020 also states that enhancing the accuracy of sentiment analysis is still an essential issue in product evaluation. Several researches had used Expectation Optimization (EM) Algorithm to make some improvements in some applications, such as in (Zhou et al., 2020 uses Bayesianbased model to analyze the comments and get the inference of user comments. Then use EM algorithm to infer the evaluation of the product (Zhou et al., 2020. Also in pattern recognition world, in (Asheri et al., 2021 a coordinatedescent EM Algorithm was used for estimating the parameters of flexibly tied GMMs that outperform basic GMM and kmeans algorithm. From several previous research it can be interpreted that EM algorithm could be used to improve the performance of Bayesian in some aspect including the accuracy. Therefore, in this study, an EM algorithm is used to analyze movie reviews and whether it could perform better than Bayesian in term of accuracy in predicting positive or negative reviews.

\section{Material and Method}

The methodology that the author uses is EM by utilizing the results of the Naïve Bayes calculation as a reference or basis for the E-step. The steps that the author takes in this study have several steps, starting from collecting material or data review from the IMDb website to testing and evaluating the accuracy results of the Naïve Bayes algorithm and EM. The following are the materials and tools that the author uses in this study, followed by a detailed description of the steps the author has taken.

\section{Materials and Tools}

The programming language that I use is python by using several libraries such as PySastrawi, beautifulsoup4, and pandas for processing datasets. Selenium webdriver to help the author get 100 reviews for each movie title because by default when opening the IMDb review page, it only loads 25 reviews, with the help of Selenium the author can mimic the mouse click on the 'Load More' button at the bottom of the review page.

Figure 1 shows the 'Load More' button which loads 25 additional reviews so that when the author is scraping, the author has to click the button three times which will make the page

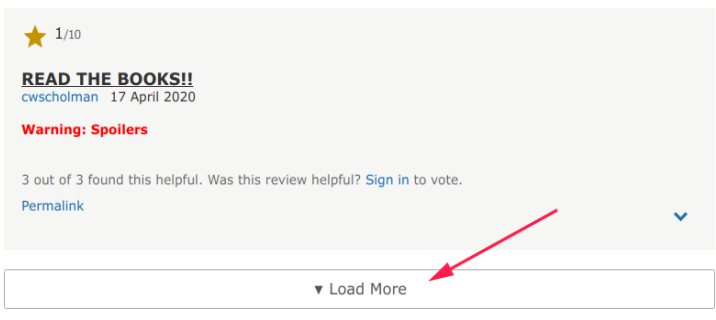

Figure 1 Load More Button

load 100 reviews.

\section{Crawling or Scraping}

At this step, the author collected data by scraping data reviews from the IMDb website. Starting by choosing ten movie titles randomly, where the ten titles have their respective titleid and each title is taken as many as 100 data reviews so that the total data review obtained is 1000 data. This data review retrieval also includes labeling for each data review. The criteria that the author applies is if the rating that the reviewer gives is 1 to 5 it will be labeled as negative while if it is 6 to 10 it will be labeled as positive. Scraping the 1000 data reviewed above, the author saves the scraped data using Commaseparated value (CSV) format. The reason the author chose the CSV format is that the Pandas library that the author use has very good support (built-in function) in processing data in the CSV format. The following is the template that the author uses to store the data review set and its labels.

Table 1 shows that there are three labels on the y-axis or column, namely the review contains data review while the label contains a label whether the data review is labeled positive or negative, if it's negative then will be labeled as $\mathrm{N}$ and labeled $\mathrm{P}$ if it is positive. The username is useful for the author when translating in the next step.

\section{Translate}

The author uses google translate to translate all the reviews. Of course, translating 1000 data reviews one by one will be quite stressful, therefore by utilizing the programming language The

Table 1 Template Dataset

\begin{tabular}{|l|l|l|}
\hline username & Review & label \\
\hline username1 & Data review ke-1 & $\mathrm{P}$ \\
\hline username2 & Data review ke-2 & $\mathrm{N}$ \\
\hline username-n & Data review ke-n & $\ldots$ \\
\hline
\end{tabular}


Almighty Python coupled with a toolkit called Selenium Webdriver, the author can translate 1000 data reviews with ease. There is one more problem, namely, in google translate itself, the maximum number of characters that can be translated at one time is 5000 characters. As expected, 5000 characters are not enough for some reviews. Before translating, the author calculates each review whether there is a review that has some characters that exceed 5000. The following is a snippet of source code that the author uses.

Table 2 shows source code above provides two pieces of information, namely the longest number of characters in the review as many as 9456 characters, and the number of reviews with more than 5000 characters as many as 8 reviews. This information shows that the previous author's assumption that the maximum number of characters allowed by google translate is 5000 characters is insufficient for some data reviews, thus making the author make a ploy so that the data review with a total of more than 5000 characters still can be translated. The strategy that the author does is to break the review string into batches consisting of words that are no more than 2300 characters, then translate them by batch per batch so that one batch of translation will not exceed the google translate limit of 5000 characters

\section{Join All Reviews}

All translated data review is ready to be combined after the previous step the author did with a separate dataset based on each titleid, so it needs to be joined into one dataset with a total of 1000 reviews.

\section{Cleaning NULL Label}

Starting with randomly choosing ten titleid. Figure 2 shows that not all reviews have a rating which makes the label column in the da-

Figure 2. Review without Rating

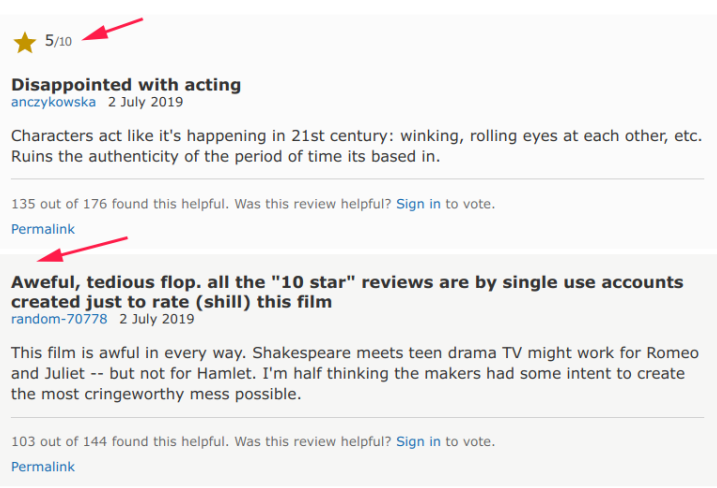

Table 2 Source Code

\begin{tabular}{|l|}
\hline src_path: str $=$ "/path/to/dataset/ \\
reviews.csv" \\
dataframe = pd.read_csv(src_path) \\
longest_char: int $=0$ \\
more_than_5000: int $=0$ \\
for_,df in dataframe.iterrows(): \\
review: str = df.get("review") \\
if len(review) $>5000:$ \\
more_than_5000 +=1 \\
if len(review) $>$ longest_char: \\
longest_char = len(review) \\
print(longest_char) \\
print(more than_5000)
\end{tabular}

taset labeled NULL as shown in figure 3. Since the data review does not have a $\mathrm{P}$ or $\mathrm{N}$ label, the author decided not to use the data and delete the data labeled NULL from the dataset. There are also some of the data reviews that have a format that is not suitable as shown in figure 4 after the translation step.

\section{Case Folding}

This step is quite simple, which is to transform all the data review's strings to lowercase.

\section{Stemming}

The last step is stemming. Stemming is where the process of mapping words in affixed sentences be the original word (without prefix, suffix, insertion, combination) which is executed by specific algorithm (Rofiqi et al., 2019 which is Naïve Bayes and EM algorithm in this case. Using the Pysastrawi library which is a python implementation of the Sastrawi library using PHP. Stemming makes all existing words reviewed into basic words as shown in Table 3.

Figure 3 Dataset with NULL Label

\begin{tabular}{|c|c|}
\hline Kirpianuscus & Dia adalah Ophella. Dan Keria kerasnny untuk itu lavak, Iri adalah fim yang inNULL \\
\hline prailiewewalker & Tiddak ada negatit tentann film ini, dengan sentuhan yang bertheda dan menaril P \\
\hline starnomena & 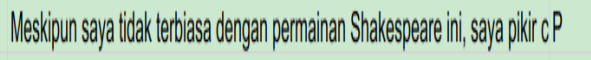 \\
\hline lavatch & 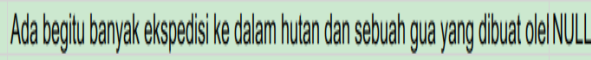 \\
\hline qheenoute & 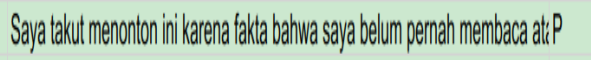 \\
\hline Gordon:11 & 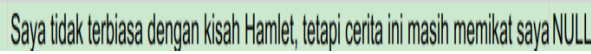 \\
\hline
\end{tabular}

Figure 4 Dataset with Unsuitable Format

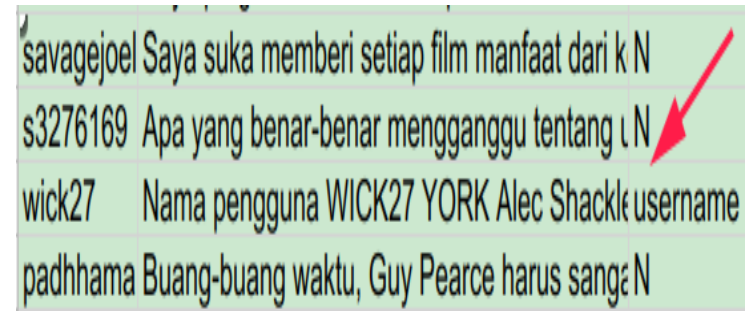


Table 3 Stemming Data Review

\begin{tabular}{|cc|}
\hline before & after \\
\hline kirim ini ke tempat sampah! & kirim sampah mov- \\
movie penghancur diri ini. & ie hancur \\
& \\
& \\
\hline
\end{tabular}

This stemming step not only makes all words into basic words but also eliminates stopwords such as symbols, hyphens, and numbers.

\section{Testing and Evaluation}

This step where the author performs data training and data testing with both algorithms Naïve Bayes and Expectation-Maximization. Evaluation comes later, and compares the resulting accuracy. Additionally, the author also counts the time that is needed by both algorithms starting from training to testing the dataset.

The author uses the same template as the training dataset for the testing dataset which then iterates over every row in the dataset and compares if the resulting of the performed testing by algorithm does not the same as the label in the same row as the review, then it will be regarded as missed and otherwise as correct. Besides missed and correct, the author also found the third condition which the author calls unknown. Unknown is the condition when the results of the testing performed by the algorithm reach zero and couldn't be calculated any further which either positive or negative get zero and that's why it is unknown. The author decided that the unknown result will be counted as missed.

\section{Naïve Bayes}

The Naïve Bayes algorithm is a classification method based on odds by calculating the total odds based on the number of trials with a combination of values that appear. Another definition of the Naiive Bayes algorithm is statistical classification that can be used to predict the probability of membership of a class. Bayesian classification is based on Bayes' theorem which has similar classification capabilities with decision trees and neural networks (Annur, 2018. The Naïve Bayes algorithm assumes that all attributes have no dependence on the value of each class variable (Aggarwal \& Zhai, 2012, or it can be said that the final probability value is the result of the initial probability which is a collection of individual probabilities (Anugrah \& Rosyid, 2019. The author uses equation from (Anugrah \& Rosyid, 2019 for the Naïve Bayes algorithm in this research. Equation (1) shows the calculation of this algorithm.

$$
\begin{aligned}
\mathrm{P}(\mathrm{H} \mid \mathrm{X}) & =\frac{\mathrm{P}(\mathrm{X} \mid \mathrm{H}) \boldsymbol{P}(\mathrm{H})}{\mathrm{P}(\mathrm{X})} \\
\mathrm{W}(\mathrm{H} \mid \mathrm{X}) & =\frac{\mathrm{P}(\mathrm{X} \mid \mathrm{H}) \boldsymbol{P}(\mathrm{H})}{\mathrm{P}(\mathrm{X})} \text { here: }
\end{aligned}
$$

- $\mathrm{X}$ is samp ${ }^{\mathrm{X}}$ le data from class (label) which is not yet known,

- $\mathrm{H}$ is the $\mathrm{H}$ predicted data from the class that already known,

- $\mathrm{P}(\mathrm{H})$ is the ${ }^{\mathrm{P}(\mathrm{H})}$ probability value of, ${ }^{\mathrm{H}}$

- $P(X)$ is $t^{H}$ he ${ }^{P(X)}$ probability value of the data sample observed,

- $\mathrm{P}(\mathrm{X} \mid \mathrm{H})$ is the $\mathrm{P}(\mathrm{X} \mid \mathrm{H})$ sample probability of $\mathrm{X}$ data, a ${ }^{\mathrm{X}}$ ssuming that the guess is correct.

\section{Expectation-Maximization}

EM mainly used by Probabilistic Latent Semantic Analysis (PLSA) to determined their parameters. In topic modeling using PLSA is able to create document contexts that are differentiated based on words that have many meanings by grouping words based on topics (Revindasari et al., 2017). The EM algorithm is designed to maximize the likelihood $\ln p(\mathbf{X}, \mathbf{Z} \mid \boldsymbol{\theta})$ by two steps, i.e., the E step and the M step. In the E step, we use the current parameters $\boldsymbol{\theta}^{\text {old }}$ to find the posterior distribution of $\mathbf{Z}$ given by $p(\mathbf{X}, \mathbf{Z} \mid \boldsymbol{\theta})$. Then we use the posterior distribution to find the expectation of the complete data likelihood Q $\left(\boldsymbol{\theta} \cdot \boldsymbol{\theta}^{\text {old }}\right)(\mathrm{Li}$ et al., 2019).

The EM algorithm is an algorithm for estimating a parameter, the initial stage is to search for the expectation value. After the expectation stage, it is continued with the stage of updating the parameter values using the Maximization algorithm. In the process of finding the expected value using the Naive Bayes algorithm, this algorithm is a class prediction method from data proposed by Thomas Bayes. In this research the author uses equation from (Anugrah \& Sarno, 2017) for the EM calculation. EM algorithm consists of two phases :

1. E Step, this phase is used to find the ap- 
proximate value of the probability of the topics in the document originating from the initial probability value (Anugrah \& Sarno, 2017). Equation (2) shows this step's calculation.

$$
P\left(c_{i} \mid d_{j}\right)=\frac{p\left(\sigma_{i}\right) \prod_{k_{j} j}^{\left|d_{j j}\right|} p\left(c_{i j}\right)}{\sum_{r=1}^{|c|} p\left(\epsilon_{i}\right) \prod_{k_{j}}^{\mid d_{j} j} p\left(c_{i}\right)}
$$

Where:

$$
\begin{aligned}
& p\left(c_{i}\right) \quad c_{i} \\
& \text { is probability of category } \\
& P\left(c_{i} \mid d_{j}\right) \quad c_{i} \\
& d_{j} \\
& \text { document , } \\
& p\left(c_{i}\right) \prod_{k_{j}}^{\left|d_{j}\right|} p\left(c_{i}\right) \\
& c_{i}{ }_{\text {in term }}^{k_{j}} \text { to document }{ }^{d_{j}} \text {. }
\end{aligned}
$$

2. Maximization Step (M Step), this phase is used to update the probability value so get the maximum probability value (Anugrah \& Sarno, 2017). Equation (3) shows this step's

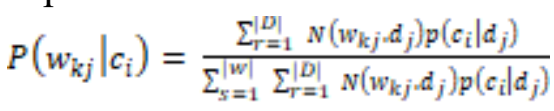

$$
\begin{aligned}
& N\left(w_{k j} \times d_{j}\right)
\end{aligned}
$$

$$
\begin{aligned}
& \text { is number of words } W_{k} \text { in the document } \\
& d_{j} \\
& |w| \text { is total number of words / features } \\
& \text { used, } \\
& N\left(w_{k j}, d_{j}\right) \\
& \text { ments. }
\end{aligned}
$$

\section{Results and Discussion \\ Scraping}

Starting with randomly choosing ten titleids as data training and five titleids as data test results in 1000 data review and 500 data review which for data training and data testing respectively. By default, IMDb only shows 25 data reviews on every page, so the author needs to mimic a mouse click that makes the review page load more 25 data reviews for every click. The author needs to click the same load more button three times so the final result will be 100 data reviews.

Figure 5 shows that chrome noticed the browser being controlled by some 'test software' which is a selenium webdriver. After getting 100 data reviews, the author saves that data to CSV format according to the template in Table 1 which makes a total 15 datasets with CSV format, 10 datasets for data training and 5 datasets for testing. Because from initial number dataset to ready-to-use dataset might differ greatly so the author keeps tracking the number for every step, Table 4 shows currently the dataset's number. The result of scraping with titleid tt5689068 is shown in Table 5 that is filled based on template in Table 1 except for the No column is only to show how many data review per titleid that got scraped.

\section{Translate}

This is quite a tricky one because of the limited number of characters allowed by google translate. Figure 6 shows how the author translates using google translate via Selenium Web-

Table 4 The Current Amount of Dataset

\begin{tabular}{|l|l|l|}
\hline titleid & \multirow{2}{*}{ 1\# scraping } & type \\
\cline { 1 - 1 } $\mathrm{tt} 5689068$ & \multirow{2}{*}{1000} & \multirow{2}{*}{ Data training } \\
\cline { 1 - 1 }$\ldots$ & & \\
\cline { 1 - 1 } $\mathrm{tt} 5717194$ & \multirow{2}{*}{500} & Data testing \\
\cline { 1 - 1 } $\mathrm{tt6148156}$ & & \\
\cline { 1 - 1 } $\mathrm{tt5813916}$ & & \\
\hline
\end{tabular}

Figure 5 Scraping with Selenium Webdriver
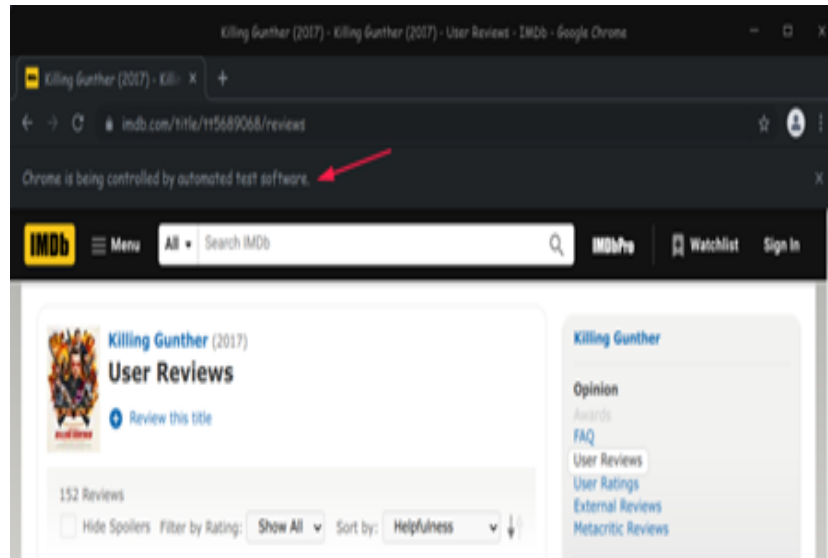
Table 5 Scraped Review With titleid tt5689068

\begin{tabular}{|c|c|c|c|}
\hline No & username & review & label \\
\hline 1 & bekariiii & $\begin{array}{l}\text { I probably never laughed } \\
\text { more in my life except } \\
\text { Kung Fury Of course it's } \\
\text { trash, but it's very funny } \\
\text { trash, once in a while you } \\
\text { need this kind of movie, } \\
\text { not serious, funny, which is } \\
\text { made just to make you } \\
\text { lough. Can't understand } \\
\text { why are you people rating } \\
\text { it so low. }\end{array}$ & $\bar{P}$ \\
\hline 2 & matze-23967 & $\begin{array}{l}\text { It's what you can call a } \\
\text { marmite movie, you either } \\
\text { love it or hate it. Best to } \\
\text { watch with some friends, } \\
\text { having some nibbles and } \\
\text { beers. } \\
\text { I felt entertained and had a } \\
\text { good time, never expected } \\
\text { it to be an Oscar contestant }\end{array}$ & $\bar{P}$ \\
\hline$\cdots$ & $\cdots$ & $\cdots$ & $\ldots$ \\
\hline$\ldots$ & $\ldots$ & $\ldots$ & $\ldots$ \\
\hline 99 & $\begin{array}{l}\text { Draadityaba- } \\
\text { jaj }\end{array}$ & $\begin{array}{l}\text { A very different action } \\
\text { comedy, also has elements } \\
\text { of 'found footage'. I was } \\
\text { surprised by the poor rat- } \\
\text { ing. I thoroughly enjoyed } \\
\text { the movie, although Arnold } \\
\text { arrives a bit late in the pic- } \\
\text { ture. } \\
\text { Please watch with an open } \\
\text { mind and don't pay heed to } \\
\text { the reviews. }\end{array}$ & $\mathrm{P}$ \\
\hline 100 & $\begin{array}{l}\text { Brunovan- } \\
\text { ael }\end{array}$ & $\begin{array}{l}\text { In a comedy I expect to } \\
\text { laugh, or have a smile on } \\
\text { my face at least once. May } \\
\text { be a matter of taste but for } \\
\text { me this movie wasn't funny } \\
\text { or fun at all. }\end{array}$ & $\mathrm{N}$ \\
\hline
\end{tabular}

driver. Just like the previous step, the author also uses selenium to translate every single data review in every dataset. Because this step only translates data in column review which contain the actual review. The template and file format to save the data will be the same as before as shown in Table 1.

For some reason that the author is not well aware of, the dataset's number decreased as shown in Table 6. Table 7 shows the result of the translated dataset with titleid tt5689068.

\section{Join All Reviews}

The author decides to combine all reviews or datasets into two datasets in this step, obviously for training and testing to make the further step a lot easier to perform. How the author handles the combined datasets filename is shown in Table

Figure 6 Translating to Indonesian

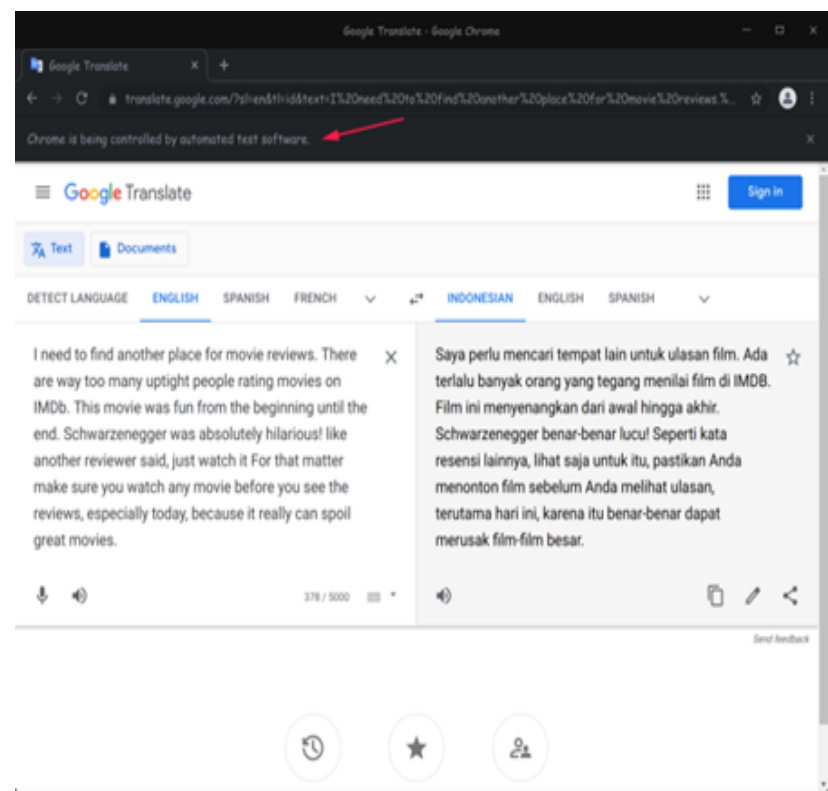

Table 6 The Current Amount of Dataset

\begin{tabular}{|c|c|c|}
\hline titleid & $\begin{array}{l}2 \# \text { trans- } \\
\text { late }\end{array}$ & type \\
\hline tt5689068 & \multirow{3}{*}{997} & \multirow{3}{*}{ Data training } \\
\hline$\ldots$ & & \\
\hline tt5717194 & & \\
\hline $\mathrm{tt} 6148156$ & \multirow{3}{*}{449} & \multirow{3}{*}{ Data testing } \\
\hline$\ldots$ & & \\
\hline tt5813916 & & \\
\hline
\end{tabular}


Journal Of Development Research, 5 (2), November 2021, Pages 94-105

Table 7 Translated Dataset With titleid tt5689068

\begin{tabular}{|c|c|c|c|}
\hline No & username & review & label \\
\hline 1 & bekariiii & $\begin{array}{l}\text { Saya mungkin tidak pernah } \\
\text { tertawa lebih dalam hidup } \\
\text { saya kecuali Kung Fury } \\
\text { tentu saja sampah, tapi itu } \\
\text { sampah yang sangat lucu, } \\
\text { sesekali Anda membutuhkan } \\
\text { movie seperti ini, tidak seri- } \\
\text { us, lucu, yang dibuat hanya } \\
\text { untuk membuat Anda lough. } \\
\text { can'tPahami mengapa kal- } \\
\text { ian memberi peringkat be- } \\
\text { gitu rendah. }\end{array}$ & $\mathrm{P}$ \\
\hline 2 & matze-23967 & $\begin{array}{l}\text { Itulah yang dapat Anda se- } \\
\text { but movie Marmite, Anda } \\
\text { menyukainya atau mem- } \\
\text { bencinya. Terbaik untuk } \\
\text { ditonton dengan beberapa } \\
\text { teman, memiliki beberapa } \\
\text { camilan dan bir. Saya mera- } \\
\text { sa terhibur dan bersenang- } \\
\text { senang, tidak pernah } \\
\text { mengharapkannya menjadi } \\
\text { kontestan Oscar }\end{array}$ & $\mathrm{P}$ \\
\hline$\ldots$ & $\cdots$ & $\ldots$ & $\ldots$ \\
\hline$\ldots$ & $\ldots$ & $\ldots$ & $\ldots$ \\
\hline 99 & Draadityabajaj & $\begin{array}{l}\text { Komedi aksi yang sangat } \\
\text { berbeda, juga memiliki ele- } \\
\text { men 'found facage'. Saya } \\
\text { terkejut dengan peringkat } \\
\text { yang buruk. Saya benar- } \\
\text { benar menikmati movie itu, } \\
\text { meskipun Arnold tiba agak } \\
\text { terlambat dalam gambar. } \\
\text { Harap tonton dengan } \\
\text { pikiran terbuka dan jangan } \\
\text { bayar Head to tinjauan. }\end{array}$ & $\mathrm{P}$ \\
\hline 100 & brunovanael & $\begin{array}{l}\text { Dalam sebuah komedi saya } \\
\text { berharap untuk tertawa, } \\
\text { atau tersenyum di wajah } \\
\text { saya setidaknya sekali. } \\
\text { Mungkin masalah selain } \\
\text { bagi saya movie ini tidak } \\
\text { lucu atau menyenangkan } \\
\text { sama sekali. }\end{array}$ & $\overline{\mathrm{N}}$ \\
\hline
\end{tabular}

8. As the author already mentioned earlier that the username column is only needed when translating so it's no longer needed and the author removes the column in this step.

Since this step only combines datasets and does not do any modifications to the datasets itself that affect the dataset's number, the
Table 8 Combine Dataset

\begin{tabular}{|c|c|c|}
\hline filename & $\begin{array}{l}\text { combined } \\
\text { filename }\end{array}$ & type \\
\hline tt5689068.csv & \multirow{3}{*}{ reviews.csv } & \multirow{3}{*}{ Data training } \\
\hline$\ldots$ & & \\
\hline tt5717194.csv & & \\
\hline tt6148156.csv & \multirow{3}{*}{ datatest.csv } & \multirow{3}{*}{ Data testing } \\
\hline$\ldots$ & & \\
\hline tt5813916.csv & & \\
\hline
\end{tabular}

dataset's number will be the same as shown in Table 6.

\section{Cleaning NULL Label}

This will be the step that greatly reduces the dataset's number. Figure 2 and 4 shows the reasons why cleaning is needed and the cleaning, in this case, means removing every single data review that has either the NULL label or unsuitable format with the template in Table 1. Manually labeling tens of data reviews is quite troublesome so the author decides to remove it from the dataset and resulting in the dataset's number decreased as shown in Table 9.

From Table 10 that contains the original training dataset before cleaned and Table 11 training dataset after getting cleaned we could see that the last two data reviews shifted up because 24 data reviews either had a NULL label or unsuited format removed from the dataset. This also applied to the testing dataset.

\section{Case Folding}

This step will not change the dataset's number since it only modifies the reviews in

Table 9 The Current Amount of Dataset

\begin{tabular}{|c|c|c|}
\hline titleid & $\begin{array}{ll}4 \# & \text { clean- } \\
\text { ing } & \\
\end{array}$ & type \\
\hline tt5689068 & \multirow{3}{*}{973} & \multirow{3}{*}{$\begin{array}{l}\text { Data train- } \\
\text { ing }\end{array}$} \\
\hline$\ldots$ & & \\
\hline tt5717194 & & \\
\hline $\mathrm{tt} 6148156$ & \multirow{3}{*}{482} & \multirow{3}{*}{$\begin{array}{l}\text { Data test- } \\
\text { ing }\end{array}$} \\
\hline & & \\
\hline $\mathrm{tt} 5813916$ & & \\
\hline
\end{tabular}


Journal Of Development Research, 5 (2), November 2021, Pages 94-105

Table 10 Original Training Dataset

\begin{tabular}{|l|l|l|}
\hline No & \multicolumn{1}{|c|}{ review } & label \\
\hline 1 & $\begin{array}{l}\text { Saya perlu mencari tempat lain untuk ulasan movie. Ada terlalu banyak orang yang tegang } \\
\text { menilai movie di IMDB. movie ini menyenangkan dari awal hingga akhir. Schwarzenegger benar- } \\
\text { benar lucu!Seperti kata resensi lainnya, lihat saja untuk itu, pastikan Anda menonton movie sebe- } \\
\text { lum Anda melihat ulasan, terutama hari ini, karena itu benar-benar dapat merusak movie-movie } \\
\text { besar. }\end{array}$ & P \\
\hline 2 & $\begin{array}{l}\text { Ketika saya dan pacar saya melihat peringkat 4. 7 di sini, harapan kami di mana rendah tetapi } \\
\text { kan lagi bahwa Anda tidak dapat memberikan skor IMDB terlalu berat. Batu movie ini!Ini } \\
\text { menghibur, lucu sekali dan langkahnya bagus. Satu-satunya kekecewaan adalah waktu layar pen- } \\
\text { dek Arnold. Abaikan skornya!Tonton saja! }\end{array}$ & P \\
\hline 205 & $\begin{array}{l}\text { movie ini mengerikan dalam segala hal. Shakespeare Meets Remaja Drama TV mungkin bekerja } \\
\text { untuk Romeo dan Juliet - tetapi tidak untuk Hamlet. Saya setengah berpikir bahwa pembuat mem- } \\
\text { iliki niat untuk menciptakan kekacauan yang paling berani. }\end{array}$ & NUL \\
\hline ... & $\begin{array}{l}\text { Aaron Stanford bukan bagian dari para pemeran movie ini, nama aktor adalah Aaron Swafford, } \\
\text { bukan hal yang sama. Lihatlah. }\end{array}$ & NULL \\
\hline 995 & $\begin{array}{l}\text { Adegan yang buruk berasal dari naskah yang buruk. Skenario bodoh. Saya terkejut, produksi } \\
\text { movie ini adalah 2020. Dumb Marshal bertemu perampok bisu. movie terburuk yang pernah saya } \\
\text { lihat!!!Terburuk dari setiap aspek sinematografi : ( }\end{array}$ & P \\
\hline 997 & $\begin{array}{l}\text { Aktingnya mengerikan dan banyak ketidakkonsistenan. Saya tidak tahu apa-apa tentang membuat } \\
\text { movie tetapi bahkan saya bisa melakukan pekerjaan yang lebih baik. }\end{array}$ & N \\
\hline
\end{tabular}

Table 11 Cleaned Training Dataset

\begin{tabular}{|c|c|c|}
\hline No & review & label \\
\hline 1 & $\begin{array}{l}\text { Saya perlu mencari tempat lain untuk ulasan movie. Ada terlalu banyak orang yang tegang menilai } \\
\text { movie di IMDB. movie ini menyenangkan dari awal hingga akhir. Schwarzenegger benar-benar lucu! } \\
\text { Seperti kata resensi lainnya, lihat saja untuk itu, pastikan Anda menonton movie sebelum Anda } \\
\text { melihat ulasan, terutama hari ini, karena itu benar-benar dapat merusak movie-movie besar. }\end{array}$ & $\bar{P}$ \\
\hline 2 & $\begin{array}{l}\text { Ketika saya dan pacar saya melihat peringkat } 4.7 \text { di sini, harapan kami di mana rendah tetapi kami } \\
\text { mencobanya karena arnold. Dan betapa senangnya kami, kami melakukannya!Ini menunjukkan lagi } \\
\text { bahwa Anda tidak dapat memberikan skor IMDB terlalu berat. Batu movie ini!Ini menghibur, lucu } \\
\text { sekali dan langkahnya bagus. Satu-satunya kekecewaan adalah waktu layar pendek Arnold. Abaikan } \\
\text { skornya!Tonton saja! }\end{array}$ & $\mathrm{P}$ \\
\hline$\ldots$ & $\ldots$ & $\ldots$ \\
\hline$\ldots$ & $\ldots$ & $\ldots$ \\
\hline 972 & $\begin{array}{l}\text { Adegan yang buruk berasal dari naskah yang buruk. Skenario bodoh. Saya terkejut, produksi movie } \\
\text { ini adalah 2020. Dumb Marshal bertemu perampok bisu. movie terburuk yang pernah saya lihat !!! } \\
\text { Terburuk dari setiap aspek sinematografi :( }\end{array}$ & $\bar{P}$ \\
\hline 973 & $\begin{array}{l}\text { Aktingnya mengerikan dan banyak ketidakkonsistenan. Saya tidak tahu apa-apa tentang membuat } \\
\text { movie tetapi bahkan saya bisa melakukan pekerjaan yang lebih baik. }\end{array}$ & $\mathrm{N}$ \\
\hline
\end{tabular}

every single row to lowercase.

The snippet of source code above shows how convenient it is to use the Pandas library since it has very good support in handling CSV format. The author only needs to prepare a function to do the convert to lowercase, read CSV format, inject the prepared function to the converters parameter and Pandas will do the rest for the author to convert every single data review in the dataset, then save the already converted Dataframe to new CSV file. Table 12 shows case foldsing step. Table 13 shows the result of this step.

\section{Stemming}

After this step is done, the datasets will be ready for training and testing then evaluate the accuracy. This step consists of some steps, besides the stemming itself and stop word removal, it also has a step that distinct data review that has an either positive or negative label. The author needs equal numbers of a positive and negative 
Table 12 Case Folding Step

src_path: str = "/path/to/src/reviews.csv"
dst_path: str = "/path/to/dst/reviews.csv"
def to_lower_case(string: str) -> str:
return string.lower()
dataset = pd.read_csv(src_path, converters=
$\quad\{$ "review": to_lower_case $\}$
dataset.to_csv(dst_path, index=False)

Table 13 Case Folding Training Dataset

\begin{tabular}{|c|c|c|c|}
\hline No & before case folding & after case folding & \\
\hline 1 & $\begin{array}{l}\text { Saya perlu mencari tempat lain untuk ulasan mov- } \\
\text { ie. Ada terlalu banyak orang yang tegang menilai } \\
\text { movie di IMDB. movie ini menyenangkan dari } \\
\text { awal hingga akhir. Schwarzenegger benar-benar } \\
\text { lucu!Seperti kata resensi lainnya, lihat saja untuk } \\
\text { itu, pastikan Anda menonton movie sebelum Anda } \\
\text { melihat ulasan, terutama hari ini, karena itu benar } \\
\text {-benar dapat merusak movie-movie besar. }\end{array}$ & $\begin{array}{l}\text { saya perlu mencari tempat lain untuk ulasan mov- } \\
\text { ie. ada terlalu banyak orang yang tegang menilai } \\
\text { movie di imdb. movie ini menyenangkan dari } \\
\text { awal hingga akhir. schwarzenegger benar-benar } \\
\text { lucu!seperti kata resensi lainnya, lihat saja untuk } \\
\text { itu, pastikan anda menonton movie sebelum anda } \\
\text { melihat ulasan, terutama hari ini, karena itu } \\
\text { benar-benar dapat merusak movie-movie besar. }\end{array}$ & $\bar{P}$ \\
\hline 2 & $\begin{array}{l}\text { Ketika saya dan pacar saya melihat peringkat } 4.7 \\
\text { di sini, harapan kami di mana rendah tetapi kami } \\
\text { mencobanya karena arnold. Dan betapa se- } \\
\text { nangnya kami, kami melakukannya!Ini menunjuk- } \\
\text { kan lagi bahwa Anda tidak dapat memberikan skor } \\
\text { IMDB terlalu berat. Batu movie ini!Ini menghibur, } \\
\text { lucu sekali dan langkahnya bagus. Satu-satunya } \\
\text { kekecewaan adalah waktu layar pendek Arnold. } \\
\text { Abaikan skornya!Tonton saja! }\end{array}$ & $\begin{array}{l}\text { ketika saya dan pacar saya melihat peringkat } 4.7 \\
\text { di sini, harapan kami di mana rendah tetapi kami } \\
\text { mencobanya karena arnold. dan betapa se- } \\
\text { nangnya kami, kami melakukannya!ini menunjuk- } \\
\text { kan lagi bahwa anda tidak dapat memberikan } \\
\text { skor imdb terlalu berat. batu movie ini!ini } \\
\text { menghibur, lucu sekali dan langkahnya bagus. } \\
\text { satu-satunya kekecewaan adalah waktu layar } \\
\text { pendek arnold. abaikan skornya!tonton saja! }\end{array}$ & $\mathrm{P}$ \\
\hline$\ldots$ & $\ldots$ & & $\cdots$ \\
\hline$\ldots$ & $\ldots$ & & \\
\hline & $\begin{array}{l}\text { Adegan yang buruk berasal dari naskah yang bu- } \\
\text { ruk. Skenario bodoh. Saya terkejut, produksi mov- } \\
\text { ie ini adalah 2020. Dumb Marshal bertemu per- } \\
\text { ampok bisu. movie terburuk yang pernah saya } \\
\text { lihat !!!Terburuk dari setiap aspek sinematografi: } \\
\text { ( }\end{array}$ & $\begin{array}{l}\text { adegan yang buruk berasal dari naskah yang } \\
\text { buruk. skenario bodoh. saya terkejut, produksi } \\
\text { movie ini adalah 2020. dumb marshal bertemu } \\
\text { perampok bisu. movie terburuk yang pernah saya } \\
\text { lihat !!!terburuk dari setiap aspek sinematografi: } \\
\text { ( }\end{array}$ & $\mathrm{P}$ \\
\hline $\begin{array}{l}97 \\
3\end{array}$ & $\begin{array}{l}\text { Aktingnya mengerikan dan banyak ketidakkon- } \\
\text { sistenan. Saya tidak tahu apa-apa tentang membu- } \\
\text { at movie tetapi bahkan saya bisa melakukan } \\
\text { pekerjaan yang lebih baik. }\end{array}$ & $\begin{array}{l}\text { aktingnya mengerikan dan banyak ketidakkon- } \\
\text { sistenan. saya tidak tahu apa-apa tentang mem- } \\
\text { buat movie tetapi bahkan saya bisa melakukan } \\
\text { pekerjaan yang lebih baik. }\end{array}$ & $\mathrm{N}$ \\
\hline
\end{tabular}

label, which means a positive label must has the same number as a negative label. Although the training dataset has 973 data as shown in Table 6 , it does not necessarily have an equal number of positive and negative. The author checks the dataset, it consists of 439 negative labels so the author needs to balance the number that makes the remaining 95 needed to be separated from the main training dataset. The author decides to join the remaining data from the training dataset to the testing dataset which makes the testing dataset's number increasing as shown in Table 14. As for the result of stemming training dataset is shown in Table 15.

\section{Testing and Evaluation}

It's time for the main course, datasets are ready and this is where the performance of both Naïve Bayes and EM algorithm is compared. The author uses 878 training datasets with a half 
Table 14 Stemming Training Dataset

\begin{tabular}{|l|l|l|l|l|}
\hline type & $\begin{array}{l}\text { before } \\
\text { split }\end{array}$ & splitting & $\begin{array}{l}\text { after } \\
\text { split }\end{array}$ & type \\
\hline $\begin{array}{l}\text { Data } \\
\text { training }\end{array}$ & 973 & 878 & 878 & $\begin{array}{l}\text { Data } \\
\text { training }\end{array}$ \\
\cline { 3 - 5 } & 95 & 577 & $\begin{array}{l}\text { Data } \\
\text { testing }\end{array}$ \\
\hline $\begin{array}{l}\text { Data } \\
\text { testing }\end{array}$ & 482 & 482 & 5 & \\
\hline
\end{tabular}

positive and half negative label, 577 as testing dataset. Besides 577 as the maximum number of testing datasets, the author also uses another range of a number of the testing dataset to see whether EM consistently has better accuracy than Naïve Bayes.

Instead of confusion matrix, because of the immense number of the data, the author uses the simple way, if the predicted result has the same label as the actual result, then the author count this as correct, maybe it's called True Positive and True Negative in the confusion matrix, and if the predicted result has a different label as an actual result, then it's counted as missed. There is another result besides correct and missed, the author calls this result unknown. The unknown is the condition when the predicted result reaches zero and couldn't be calculated any further which either positive or negative get zero and that's why it is unknown. The author counts this unknown as missed. Table 16, 17, 18, 19 and 20 shows that the author uses different numbers of dataset for testing. How the author calculates the final accuracy is shown in (4).

$$
\text { Accuracy }=\frac{\text { Correct }}{\text { Correct }+ \text { Missed }+ \text { Unkown }} \times 100
$$

Table $16,17,18,19$, and 20 are clearly shows that EM consistently has accuracy better than Naïve Bayes, although the larger the testing dataset is, the lower the EM's accuracy, but still, it consistently has accuracy more than 70\% meanwhile Naïve Bayes accuracy never reach $70 \%$

Table 15 Stemming Training Dataset

\begin{tabular}{|c|c|c|c|}
\hline No & before stemming & after stemming & $\overline{\text { label }}$ \\
\hline 1 & $\begin{array}{l}\text { Saya perlu mencari tempat lain untuk ulasan movie. Ada } \\
\text { terlalu banyak orang yang tegang menilai movie di IMDB. } \\
\text { movie ini menyenangkan dari awal hingga akhir. } \\
\text { Schwarzenegger benar-benar lucu!Seperti kata resensi } \\
\text { lainnya, lihat saja untuk itu, pastikan Anda menonton movie } \\
\text { sebelum Anda melihat ulasan, terutama hari ini, karena itu } \\
\text { benar-benar dapat merusak movie-movie besar. }\end{array}$ & $\begin{array}{l}\text { cari ulas movie tegang nilai movie imdb } \\
\text { movie senang schwarzenegger benarbe- } \\
\text { nar lucuseperti resensi pasti tonton movie } \\
\text { ulas benarbenar rusak moviemovie }\end{array}$ & $\mathrm{P}$ \\
\hline 2 & $\begin{array}{l}\text { Ketika saya dan pacar saya melihat peringkat } 4.7 \text { di sini, } \\
\text { harapan kami di mana rendah tetapi kami mencobanya ka- } \\
\text { rena arnold. Dan betapa senangnya kami, kami } \\
\text { melakukannya!Ini menunjukkan lagi bahwa Anda tidak } \\
\text { dapat memberikan skor IMDB terlalu berat. Batu movie ini! } \\
\text { Ini menghibur, lucu sekali dan langkahnya bagus. Satu- } \\
\text { satunya kekecewaan adalah waktu layar pendek Arnold. } \\
\text { Abaikan skornya!Tonton saja! }\end{array}$ & $\begin{array}{l}\text { pacar peringkat } 47 \text { harap rendah coba } \\
\text { arnold betapa senang melakukannyaini } \\
\text { skor imdb berat batu movie iniini hibur } \\
\text { lucu langkah bagus satusatunya kecewa } \\
\text { layar pendek arnold abai skornyatonton }\end{array}$ & $\bar{P}$ \\
\hline$\cdots$ & $\cdots$ & & $\cdots$ \\
\hline$\cdots$ & $\cdots$ & & $\cdots$ \\
\hline 972 & $\begin{array}{l}\text { Adegan yang buruk berasal dari naskah yang buruk. Ske- } \\
\text { nario bodoh. Saya terkejut, produksi movie ini adalah } 2020 . \\
\text { Dumb Marshal bertemu perampok bisu. movie terburuk } \\
\text { yang pernah saya lihat !!!Terburuk dari setiap aspek sine- } \\
\text { matografi :( }\end{array}$ & $\begin{array}{l}\text { adegan buruk asal naskah buruk skenario } \\
\text { bodoh kejut produksi movie } 2020 \text { dumb } \\
\text { marshal temu rampok bisu movie buruk } \\
\text { buruk aspek sinematografi }\end{array}$ & $\mathrm{P}$ \\
\hline 973 & $\begin{array}{l}\text { Aktingnya mengerikan dan banyak ketidakkonsistenan. Saya } \\
\text { tidak tahu apa-apa tentang membuat movie tetapi bahkan } \\
\text { saya bisa melakukan pekerjaan yang lebih baik. }\end{array}$ & $\begin{array}{l}\text { akting keri ketidakkonsistenan apaapa } \\
\text { movie kerja }\end{array}$ & $\mathrm{N}$ \\
\hline
\end{tabular}


Table 16 Testing Result With 150 Datasets

\begin{tabular}{|c|l|l|l|}
\hline \multicolumn{2}{|c|}{} & \multicolumn{2}{|l|}{ Algorithm } \\
\cline { 3 - 4 } \multicolumn{2}{|c|}{} & Naïve Bayes & EM \\
\hline R & Unknown & 10 & 12 \\
$\mathrm{e}$ & & & \\
\cline { 2 - 4 } $\mathrm{s}$ & Missed & 40 & 27 \\
$\mathrm{u}$ & Correct & 100 & 111 \\
$\mathrm{n}$ & & & $74 \%$ \\
\cline { 2 - 4 } $\mathrm{t}$ & Accuracy & $67 \%$ & \\
\hline
\end{tabular}

Table 17 Testing Result With 250 Datasets

\begin{tabular}{|c|c|c|c|}
\hline & \multicolumn{2}{|l|}{ Algorithm } \\
\hline & & Naïve Bayes & EM \\
\hline \multirow{4}{*}{$\begin{array}{l}\mathrm{R} \\
\mathrm{e} \\
\mathrm{s} \\
\mathrm{u} \\
\mathrm{l} \\
\mathrm{t}\end{array}$} & Unknown & 26 & 29 \\
\hline & Missed & 64 & 41 \\
\hline & Correct & 160 & 180 \\
\hline & Accuracy & $64 \%$ & $72 \%$ \\
\hline
\end{tabular}

Table 18 Testing Result With 350 Datasets

\begin{tabular}{|c|c|c|c|}
\hline & \multicolumn{2}{|l|}{ Algorithm } \\
\hline & & Naïve Bayes & EM \\
\hline \multirow{2}{*}{$\begin{array}{l}\mathrm{R} \\
\mathrm{e}\end{array}$} & Unknown & 35 & 38 \\
\hline & Missed & 85 & 63 \\
\hline \multirow{2}{*}{$\begin{array}{l}\mathrm{u} \\
\mathrm{l} \\
\mathrm{t}\end{array}$} & Correct & 230 & 249 \\
\hline & Accuracy & $66 \%$ & $71 \%$ \\
\hline
\end{tabular}

Table 19 Testing Result With 450 Datasets

\begin{tabular}{|c|c|c|c|}
\hline & \multicolumn{2}{|l|}{ Algorithm } \\
\hline & & Naïve Bayes & EM \\
\hline \multirow{4}{*}{$\begin{array}{l}\mathrm{R} \\
\mathrm{e} \\
\mathrm{s} \\
\mathrm{u} \\
\mathrm{l} \\
\mathrm{t}\end{array}$} & Unknown & 41 & 44 \\
\hline & Missed & 112 & 91 \\
\hline & Correct & 297 & 315 \\
\hline & Accuracy & $66 \%$ & $70 \%$ \\
\hline
\end{tabular}

Table 20 Testing Result With 577 Datasets

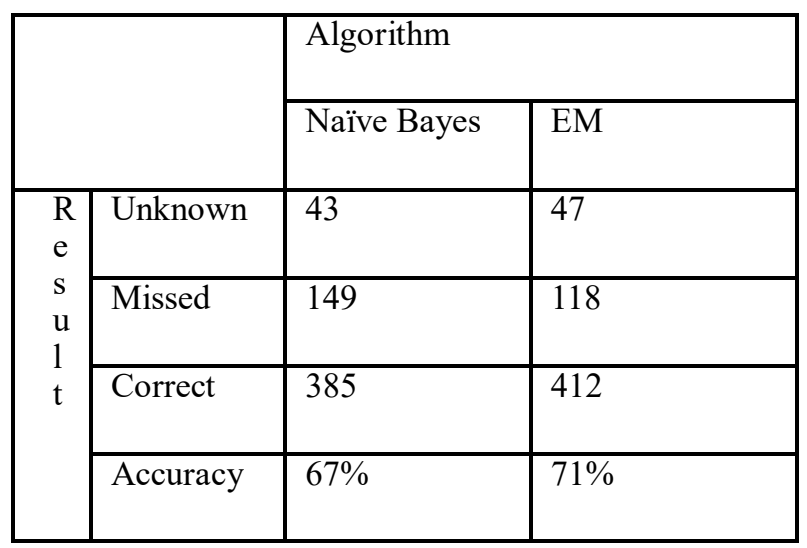

Table 21 Time Consumed by Naïve Bayes and EM

\begin{tabular}{|l|l|l|l|}
\hline & Dataset & Naïve Bayes & EM \\
\hline \multirow{4}{*}{$\begin{array}{l}\mathrm{T} \\
\mathrm{i}\end{array}$} & 150 & $20.9 \mathrm{~s}$ & $2215.4 \mathrm{~s}$ \\
\cline { 2 - 4 } $\mathrm{m}$ & 250 & $20.5 \mathrm{~s}$ & $3351.3 \mathrm{~s}$ \\
\cline { 2 - 4 } $\mathrm{e}$ & 350 & $23 \mathrm{~s}$ & $3515.6 \mathrm{~s}$ \\
\cline { 2 - 4 } & 450 & $18 \mathrm{~s}$ & $4473.3 \mathrm{~s}$ \\
\cline { 2 - 4 } & 557 & $20.5 \mathrm{~s}$ & $5858.7 \mathrm{~s}$ \\
\hline
\end{tabular}

and thus proved that EM algorithm has a better result than Naïve Bayes in this particular case which is movie review that has so many tokens that eventually produce a huge bag of words.

Additionally, the author also notes the time that both algorithms took to perform the training and testing, unsurprisingly Naïve Bayes has the upper hand in this field. As the author already mentioned at the very beginning of this paper, Table 21 shows that how fast Naïve Bayes compared to EM, no matter how much the dataset is, has no real effect on how fast Naïve Bayes is. Although EM really did a good job to have better accuracy but it also comes with a tradeoff which is the time that it consumes.

\section{Conclusion}

In this research, the author uses EM as the alternative to the most used algorithm for opinion mining Naïve Bayes. This research uses 878 training datasets that consist of the half with the positive label and another half with the negative label from IMDb's movie review and 577 as testing datasets. Accuracy that Naïve Bayes got is $67 \%$ but after the uses of EM as the alternative algorithm of Naïve Bayes, the accuracy that EM got is $71 \%$, there is an increase of accuracy by $4 \%$ and thus also proves that EM has better accuracy than Naïve Bayes on opinion mining in movie reviews case studies. The only tradeoff that EM comes with is that it takes a much longer time and consumes a lot of resource which is the processor than it took to perform the same dataset as Naïve Bayes.

\section{References}

Kulkarni, D. S., \& Rodd, S. F. (2018). Extensive study of text based methods for opinion mining. Proceedings of the 2nd International Conference on Inventive Systems and Control, ICISC 2018, Icisc, 523-527. https://doi.org/10.1109/ ICISC.2018.8399127

Vijay, R., Vangara, B., Thirupathur, K., \& Vangara, S. P. (2020). Opinion Mining 
Classification using Naive Bayes Algorithm. International Journal of Innovative Technology and Exploring Engineering, 9 (5), 495-498. https://doi.org/10.35940/ ijitee.e2402.039520

Harahap, F., Harahap, A. Y. N., Ekadiansyah, E., Sari, R. N., Adawiyah, R., \& Harahap, C. B. (2019). Implementation of Naïve Bayes Classification Method for Predicting Purchase. 2018 6th International Conference on Cyber and IT Service Management, CITSM 2018, Citsm, 1-5. https:// doi.org/10.1109/CITSM.2018.8674324

Ilham Esa Tiffani. (2020). Optimization of Naive Bayes Classifier By Implemented Unigram, Bigram, Trigram for Sentiment Analysis of Hotel Review. In Joscex (Vol. 1, pp. 1-7).

Pugsee, P., \& Chatchaithanawat, T. (2020). Opinion mining for laptop reviews using naïve bayes. Current Applied Science and Technology, 20(2), 278-294. https:// doi.org/10.14456/cast.2020.16

Pugsee, P., Nussiri, V., \& Kittirungruang, W. (2019). Opinion mining for skin care products on twitter. Communications in Computer and Information Science, 937, 261271. https://doi.org/10.1007/978-981-133441-2_20

Poovaraghan, R. J., Keerti Priya, M. V., Sai Surya Vamsi, P. V., Mansi Mewara, M. M., \& Loganathan, S. (2019). Fake news accuracy using naive bayes classifier. International Journal of Recent Technology and Engineering, 8(1C2), 962-964.

Granik, M., \& Mesyura, V. (2017). Fake news detection using naive Bayes classifier. 2017 IEEE 1st Ukraine Conference on Electrical and Computer Engineering, UKRCON 2017 - Proceedings, 900-903. https://doi.org/10.1109/

UKRCON.2017.8100379

Novendri, R., Callista, A. S., Pratama, D. N., \& Puspita, C. E. (2020). Sentiment Analysis of YouTube Movie Trailer Comments Using Naïve Bayes. Bulletin of Computer Science and Electrical Engineering, 1(1), 2632. https://doi.org/10.25008/bcsee.v1i1.5

Zhou, T., Wang, X., \& Fang, Y. (2020). HARK: Harshness-Aware Sentiment Analysis Framework for Product Review. AAAI 2020 - 34th AAAI Conference on Artificial Intelligence, 13993-13994.
Li, X., Zhong, Z., Wu, J., Yang, Y., Lin, Z., \& Liu, H. (2019). Expectation-maximization attention networks for semantic segmentation. Proceedings of the IEEE International Conference on Computer Vision, 2019. Octob, 9166-9175. https://doi.org/10.1109/ ICCV.2019.00926

Asheri, H., Hosseini, R., \& Araabi, B. N. (2021). A new EM algorithm for flexibly tied GMMs with large number of components. Pattern Recognition, 114. https:// doi.org/10.1016/j.patcog.2021.107836

Rofiqi, M. A., Fauzan, A. C., Agustin, A. P., \& Saputra, A. A. (2019). Implementasi TermFrequency Inverse Document Frequency (TF-IDF) Untuk Mencari Relevansi Dokumen Berdasarkan Query. ILKOMNIKA: Journal of Computer Science and Applied Informatics, 1(2), 58-64. https:// doi.org/10.28926/ilkomnika.vli2.18

Annur, H. (2018). Klasifikasi Masyarakat Miskin Menggunakan Metode Naive Bayes. ILKOM Jurnal Ilmiah, 10(2), 160 165. https://doi.org/10.33096/ ilkom.v10i2.303.160-165

Aggarwal, C. C., \& Zhai, C. X. (2012). A survey of text classification algorithms. Mining Text Data, 9781461432, 163-222. https://doi.org/10.1007/978-1-4614-322346

Anugră, I. G., \& Rosyid, H. (2019). Penerapan Information Retrieval Menggunakan Pemodelan Topik Pada Deskripsi Portal Multimedia. Jurnal Nasional Komputasi Dan Teknologi Informasi (JNKTI), 2(1), $48 . \quad$ https://doi.org/10.32672/ jnkti.v2i1.1057

Revindasari, F., Sarno, R., \& Solichah, A. (2017). Traceability between business process and software component using Probabilistic Latent Semantic Analysis. 2016 International Conference on Informatics and Computing, ICIC 2016, Icic, 245-250. https://doi.org/10.1109/IAC.2016.7905723

Anugrah, I. G., \& Sarno, R. (2017). Business Process model similarity analysis using hybrid PLSA and WDAG methods. Proceedings of 2016 International Conference on Information and Communication Technology and Systems, ICTS 2016, 231-236. https://doi.org/10.1109/

ICTS.2016.7910304 